\title{
Analysis of Symmetrical and Asymmetrical Current Source Multilevel Inverter
}

\author{
D. Tamilarasi1, T. S. Sivakumaran² \\ ${ }^{1}$ Department of EEE, Anna University, Chennai, India \\ ${ }^{2}$ Department of EEE, Arunai College of Engineering, Tiruvannamalai, India \\ Email: tamilarasid@arunai.edu.in, sivakumarants@arunai.edu.in
}

How to cite this paper: Tamilarasi, D. and Sivakumaran, T.S. (2016) Analysis of Symmetrical and Asymmetrical Current Source Multilevel Inverter. Circuits and Systems, 7, 3469-3484.

http://dx.doi.org/10.4236/cs.2016.711295

Received: May 6, 2016

Accepted: May 18, 2016

Published: September 6, 2016

Copyright $\odot 2016$ by authors and Scientific Research Publishing Inc. This work is licensed under the Creative Commons Attribution International License (CC BY 4.0).

http://creativecommons.org/licenses/by/4.0/

\begin{abstract}
The paper proposes a Current Source Multilevel Inverter (CSMLI) with single rating inductor topology. Multilevel inverters are most familiar with power converter's applications due to reduced $\mathrm{d} v / \mathrm{d} t, \mathrm{~d} i / \mathrm{d} t$ stress, and very efficient for reducing harmonic distortion in the output voltage and output current. The proposed nine-level current source inverter has been tested under symmetrical and asymmetrical modes of operation, and their activities are compared using PI and Fuzzy PI (Proportional Integral) controllers with multicarrier PWM (Pulse Width Modulation) strategy. MATLAB/Simulink simulation has been made for the proposed converter to obtain its performance measures. Some experimental results are given to verify the presented Current Source Multilevel Inverter.
\end{abstract}

\section{Keywords}

Current Source Inverter, Multilevel Inverter, Multicarrier PWM, Total Harmonic Distortion, Fuzzy PI Controller

\section{Introduction}

Multilevel inverters can offer substantial benefits for higher power applications, including reduced harmonics, and increased power ratings because of reduced switching device voltage and current stresses. Multilevel inverters have been shown more consideration [1]-[3]. Multilevel inverters comprise of power semiconductors and DC voltage sources, the output of which creates voltages with stepped waveforms. The multilevel inverter configuration can be categorized into the Voltage Source Multilevel Inverter (VSMLI) and Current Source Multilevel Inverter (CSMLI) [4]-[6]. Multilevel VSI has DC voltage power source and produces an AC output to the load, whereas Multilevel 
Current Source Inverter delivers predetermine AC output from a single or more DC sources due to its high impedance DC power supply. The MCSI has the features of short circuit protection, lower voltage and current stress and less THD in the output waveforms [7]-[10]. The introduction of current source inverters (CSIs) into this field could lead to marketing advantages due to the advantageous characteristics of this currently less used converter topology. These advantages including: 1) a simple structure; 2) short-circuit protection; 3) bidirectional operation; 4) nearly sinusoidal inputs and outputs; 5) the absence of electrolytic capacitors; and 6) the possibility to connect in series GTO or GCT, make the use of CSI in high-power medium-voltage drives highly desirable [11].

Current Source Inverters with pulse width modulation strategies are employed to deliver a minimum distorted input and output waveforms. This inverter circuit is the double cascaded H-bridge multilevel Current Source Inverter. Tragically, the need for isolated DC sources, power devices, and their gating circuits are a few issues of this inverter circuit. Reference [12] introduced the multilevel CSI topology utilizing H-bridge and inductor-cell. This topology streamlines the necessity of isolated DC sources in the parallel H-bridge multilevel CSI. An alternate circuit design of multilevel CSI is made by using a multi-cell arrangement of multilevel CSI [13]-[15], which is the double flying capacitor multilevel VSI. Various control, strategies have been exhibited to control the voltage at intermediate levels and highlighted in [16]-[18]. However, the inverter still requires expensive larger size middle inductors $(>100 \mathrm{mH})$. These inductors will result in more losses in the inverter circuits and the inverter circuits will have lower efficiency.

This paper presents a nine-level single phase single inductor current source inverter using multicarrier PWM strategy controlled with PI and Fuzzy PI Controller. The Fuzzy PI control algorithm that combines the fuzzy logic control results in suitable nonlinear characteristics and efficiently reduces the error in power extraction [19].

\section{Current Source Multilevel Inverter (CSMLI)}

A current source inverter converts the input DC to an AC at its output terminals. In these inverters, the input voltage is kept constant, and the amplitude of output voltage does not depend on the load. Nevertheless, the wave form of load current, as well as its magnitude, depends on the nature of the load impedance. In this inverter, the input current is constant, but adjustable. The amplitude of output current from CSI independent of the load. A DC source supplies current Source Inverter. In an adjustable speed drive (ASD), DC source is usually an AC/DC rectifier with a large inductor to provide stable current supply. Usually, a CSI has a boost operation function, its output voltage peak value can be higher than the DC-link voltage [20]-[23].

\subsection{Nine-Level Single Rating Inductor Type Symmetrical Current Source Inverter}

Figure 1 shows the power circuit of the proposed nine level single rating inductor type 
symmetrical current source inverter. From this figure, it is observed that the circuit model is obtained by connecting four $\mathrm{H}$-bridge unidirectional controlled power devices, and a DC source with equal inductors L. The DC module is working with different intermediate levels for nine-level output waveform generation. All DC sources connected at the common point, due to this the isolated DC sources are no longer necessary in the circuit. The switching sequences for nine level single rating inductor type symmetrical current source inverter shown in Figure 2 and Table 1. The switching sequences show the current level generation of positive, negative and zero level of $+\mathrm{I},+2 \mathrm{I}$, $+3 \mathrm{I},+4 \mathrm{I},-\mathrm{I},-2 \mathrm{I},-3 \mathrm{I},-4 \mathrm{I}$ and 0 respectively.

\subsection{Pulse Width Modulation (PWM)}

In the proposed CSI topology, a level based multicarrier PWM strategy implemented for firing the gate terminals of the MOSFET to obtain the current waveform of ninelevel CSI. Multicarrier PWM strategy is a comparison of a reference waveform, with vertically shifted carrier signals. In multicarrier PWM technique, $m-1$ triangular carriers are used for m-level inverter output voltage or current. In this proposed topology,

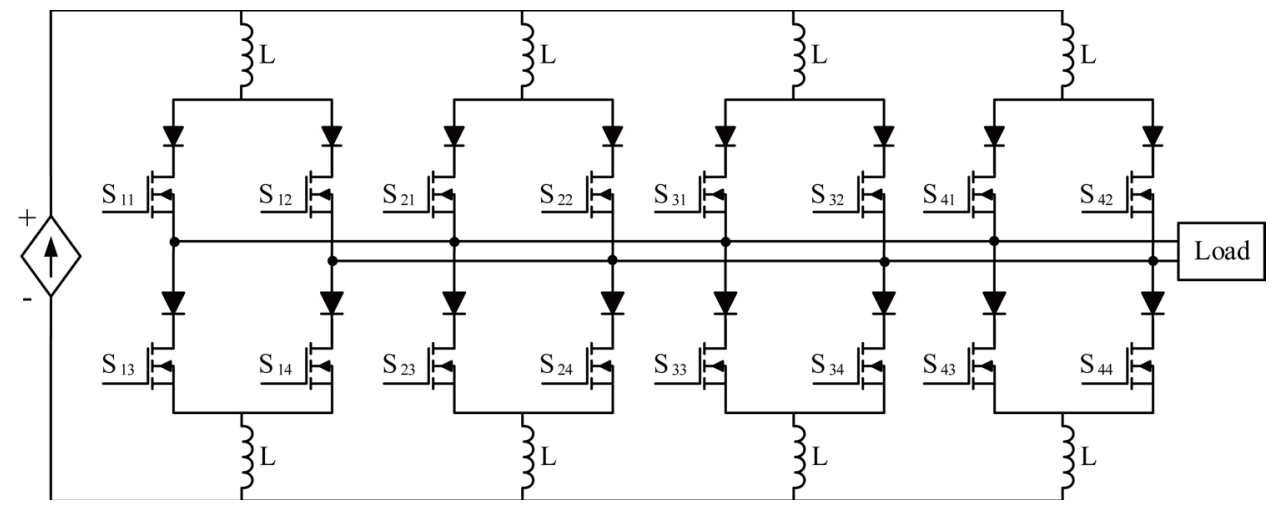

Figure 1. Proposed nine level single rating type inductor symmetrical current source Inverter.

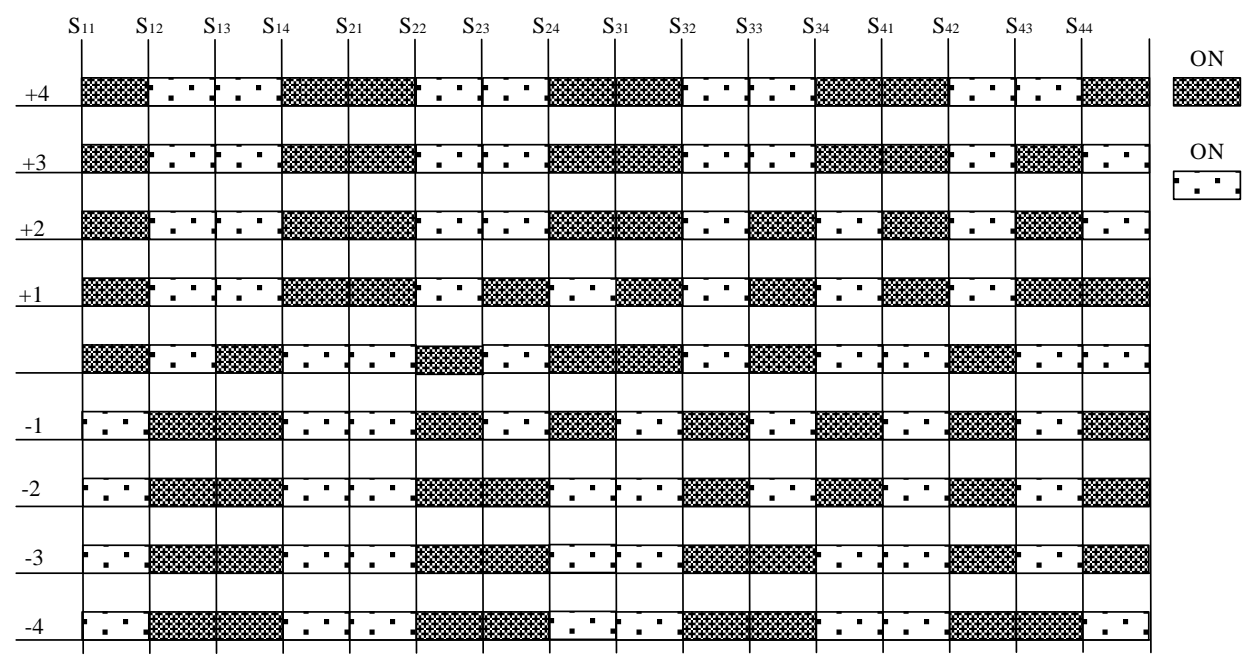

Figure 2. Switching sequence of symmetrical nine level current source inverter. 
eight triangular carriers are preferred. In Phase Opposition Disposition (POD), the carriers above the Sinusoidal reference zero points are 180 out of phase with those below the zero point. Figure 3 shows the gate pulse generation of proposed CSI with POD strategy with sine reference of modulation index $m_{a}=0.9$ and the carrier frequency of 2 $\mathrm{kHz}$. The carrier waveforms have same amplitude Ac and frequency $f_{c}$. Similarly, the reference waveforms have frequency $f_{\text {ref }}$ and amplitude $A_{\text {ref }}$. At every instant, the response of the comparator is decoded to generate the correct switching sequences with respect to the output of the inverter. The frequency modulation index $\left(m_{f}\right)$ and amplitude modulation index (ma) calculated in Equations (1) and (2) [24] [25]. In the level shifted multicarrier PWM, Phase Opposite Disposition (POD) strategy is used.

$$
\begin{gathered}
m_{f}=\frac{f_{c}}{f_{\text {ref }}} \\
m_{a}=\frac{A_{\text {ref }}}{(m-1) A_{c}}
\end{gathered}
$$

\subsection{Nine-Level Single Rating Inductor Type Asymmetrical CSI}

Figure 4 shows the power circuit of the proposed nine level single rating inductor

Table 1. Switching sequence of proposed symmetrical nine-level single rating Inductor CSI.

\begin{tabular}{ccccccccccccccccc}
\hline Level & $S_{11}$ & $S_{12}$ & $S_{13}$ & $S_{14}$ & $S_{21}$ & $S_{22}$ & $S_{23}$ & $S_{24}$ & $S_{31}$ & $S_{32}$ & $S_{33}$ & $S_{34}$ & $S_{41}$ & $S_{42}$ & $S_{43}$ & $S_{44}$ \\
\hline+4 & On & Off & Off & On & On & Off & Off & On & On & Off & Off & On & On & Off & Off & On \\
+3 & On & Off & Off & On & On & Off & Off & On & On & Off & Off & On & On & Off & On & Off \\
+2 & On & Off & Off & On & On & Off & Off & On & on & Off & On & Off & On & Off & On & Off \\
+1 & On & Off & Off & On & On & Off & On & Off & On & Off & On & Off & On & Off & On & Off \\
0 & On & Off & On & off & Off & On & Off & On & on & off & On & Off & Off & On & Off & On \\
-1 & Off & On & On & Off & Off & On & Off & On & Off & On & Off & On & Off & On & Off & on \\
-2 & Off & On & On & Off & Off & On & On & Off & Off & On & Off & On & Off & On & Off & On \\
-3 & Off & On & on & Off & Off & On & On & Off & Off & On & On & Off & Off & On & Off & On \\
-4 & off & on & on & off & off & on & on & off & off & on & on & off & off & on & on & off \\
\hline
\end{tabular}

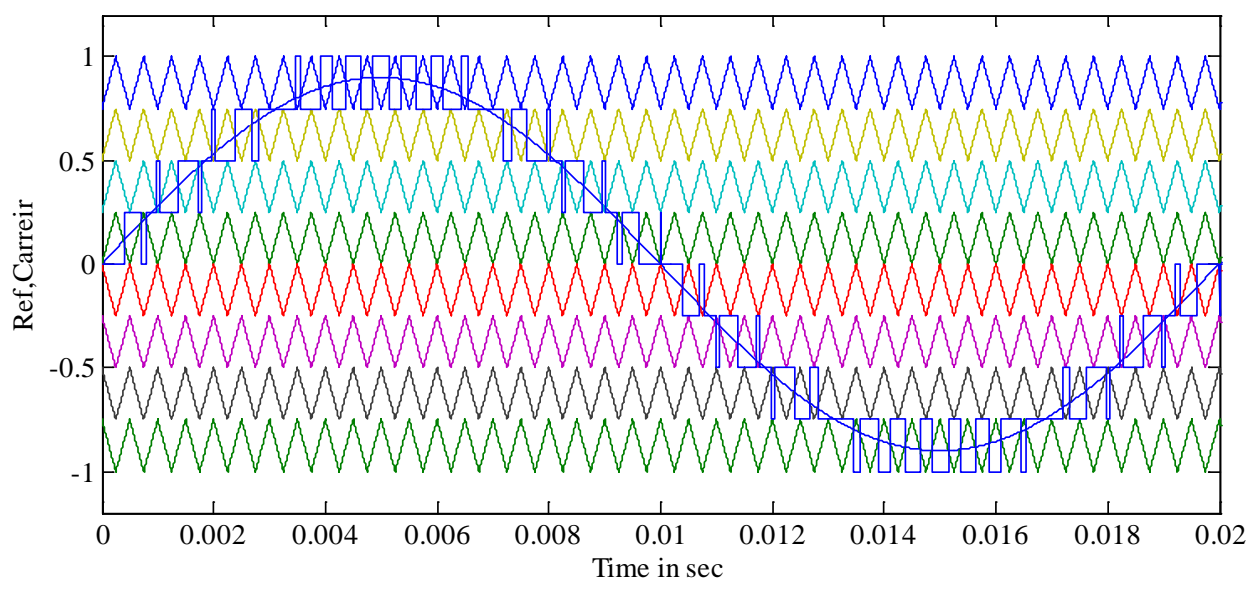

Figure 3. Gate pulse generation of proposed nine-level current source inverter. 
asymmetrical current source inverter. From this figure, it is observed that the circuit model is obtained by connecting two $\mathrm{H}$-bridge, unidirectional controlled power devices and a DC source with inductors. It is implemented using the power circuit consists of eight IGBT switches, and two pairs of inductors of L11 and L12 whose values are 300 $\mathrm{mH}$ and L21 and L22 are $100 \mathrm{mH}$ with a common current source. The switching sequences for nine level single rating inductor asymmetrical current source inverter shown in Table 2. The switching sequences shows the symmetrical nine-level current generation with addition and subtraction process of inverter. i.e. active level $+\mathrm{I}(\mathrm{I}+0)$, $+2 \mathrm{I}(3 \mathrm{I}-\mathrm{I}),+3 \mathrm{I}(3 \mathrm{I}+0),+4 \mathrm{I}(3 \mathrm{I}+\mathrm{I})$, negative level $-\mathrm{I}(-\mathrm{I}+0),-2 \mathrm{I}(-3 \mathrm{I}+\mathrm{I}),-3 \mathrm{I}(-3 \mathrm{I}$ $+0),-4 \mathrm{I}(-3 \mathrm{I}-\mathrm{I})$ and 0 respectively.

\section{Simulation Results}

The Simulink representation of nine level single rating inductor type symmetrical current source inverter is implemented and this power circuit consists of sixteen IGBT

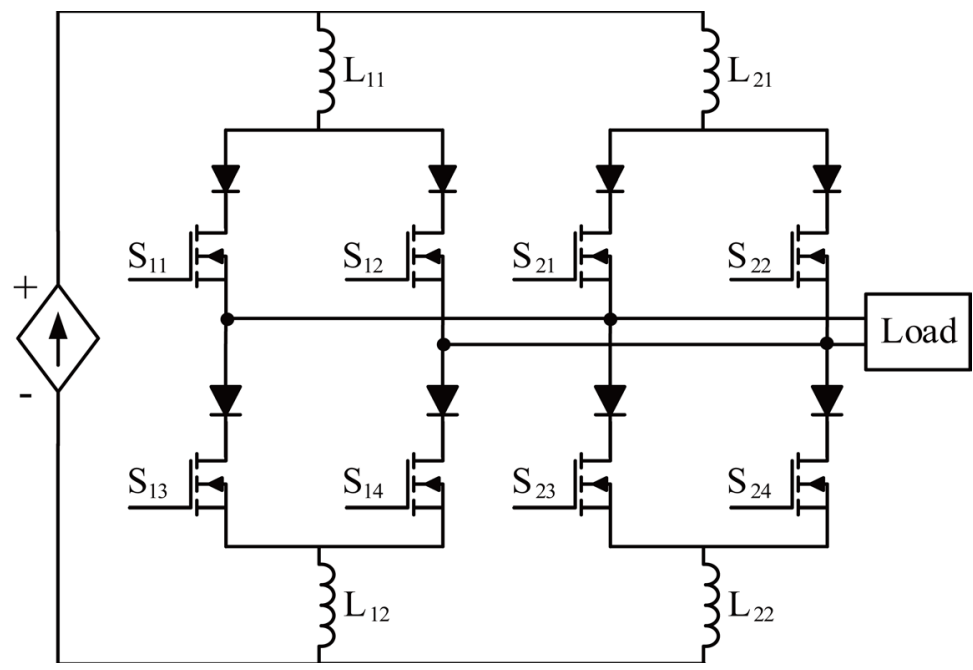

Figure 4. Proposed nine level single rating type inductor asymmetrical current source inverter.

Table 2. Switching sequence of proposed asymmetrical nine level single rating inductor CSI.

\begin{tabular}{cllllllll}
\hline Level & $\mathrm{S}_{11}$ & $\mathrm{~S}_{12}$ & $\mathrm{~S}_{13}$ & $\mathrm{~S}_{14}$ & $\mathrm{~S}_{21}$ & $\mathrm{~S}_{22}$ & $\mathrm{~S}_{23}$ & $\mathrm{~S}_{24}$ \\
\hline+4 & On & Off & Off & On & On & Off & Off & on \\
+3 & On & Off & On & Off & On & Off & Off & on \\
+2 & Off & On & On & Off & On & Off & off & on \\
+1 & On & Off & Off & On & On & Off & on & off \\
0 & On & Off & On & Off & Off & On & Off & On \\
-1 & Off & On & On & Off & Off & On & off & on \\
-2 & On & Off & Off & On & Off & On & On & off \\
-3 & Off & On & Off & On & Off & On & On & off \\
-4 & off & on & on & off & off & on & on & off \\
\hline
\end{tabular}


switches and eight identical inductors with rating of $100 \mathrm{mH}$ with a common current source generated from PV array. The current source shared by the four H-bridge inverter with suitable switching sequences generate the nine level output. Multi-carrier pulse width modulation is tuned with proposed PI and Fuzzy PI Controller. Figure 5 shows the current harmonic response of symmetrical nine-level CSI, which shows the total current harmonic distortion to be $14.31 \%$. In the spectrum analysis, the total harmonic produced is $14.31 \%$. Maximum amount of low order harmonics has been removed and the order of the harmonics is less than $0.5 \%$ except fundamental. Figures 6-9 show the overall simulated responses of the nine level single rating inductor symmetrical current source inverter with PI and fuzzy PI controllers and their output responses obtained.

Figure 6 and Figure 7 show the individual responses of symmetrical nine-level current source inverter output current, voltage and $\mathrm{I}_{\mathrm{rms}}$ tuned with PI controller and fuzzy PI controller respectively with a set value of $I_{\mathrm{rms}}$ as 2 A. Figure 8 shows the current responses comparison of PI and Fuzzy Controller of symmetrical CSI for a step change in load current. From Figure 8, it is observed that when the load current is suddenly incremented from $2 \mathrm{~A}$ to $3 \mathrm{~A}$ at $t=1 \mathrm{~s}$ and decremented from $3 \mathrm{~A}$ to $2 \mathrm{~A}$ with respect to time, $t=2 \mathrm{~s}$. During this instant regulatory response were obtained and it observed that the fuzzy PI controller response has been settled very fast with its reference current without any oscillation compared with PI controller.

Similarly, the Figure 9 shows the current responses comparison of PI and Fuzzy Controller of symmetrical CSI for the same change in input. From the Figure 9, it is noted that the input current has been suddenly increased from $4 \mathrm{~A}$ to $5 \mathrm{~A}$ at $t=1 \mathrm{~s}$ and back to $4 \mathrm{~A}$ at $t=2 \mathrm{~s}$. During this servo response, the fuzzy PI controller response has been converged quickly compared with PI controller which has shown in Table 3.

Multicarrier pulse width modulation strategy is implemented for IGBT switching with PI and Fuzzy PI Controller. Figure 10 shows the current harmonic response of asymmetrical nine-level CSI, with the total current harmonic distortion of $14.26 \%$.

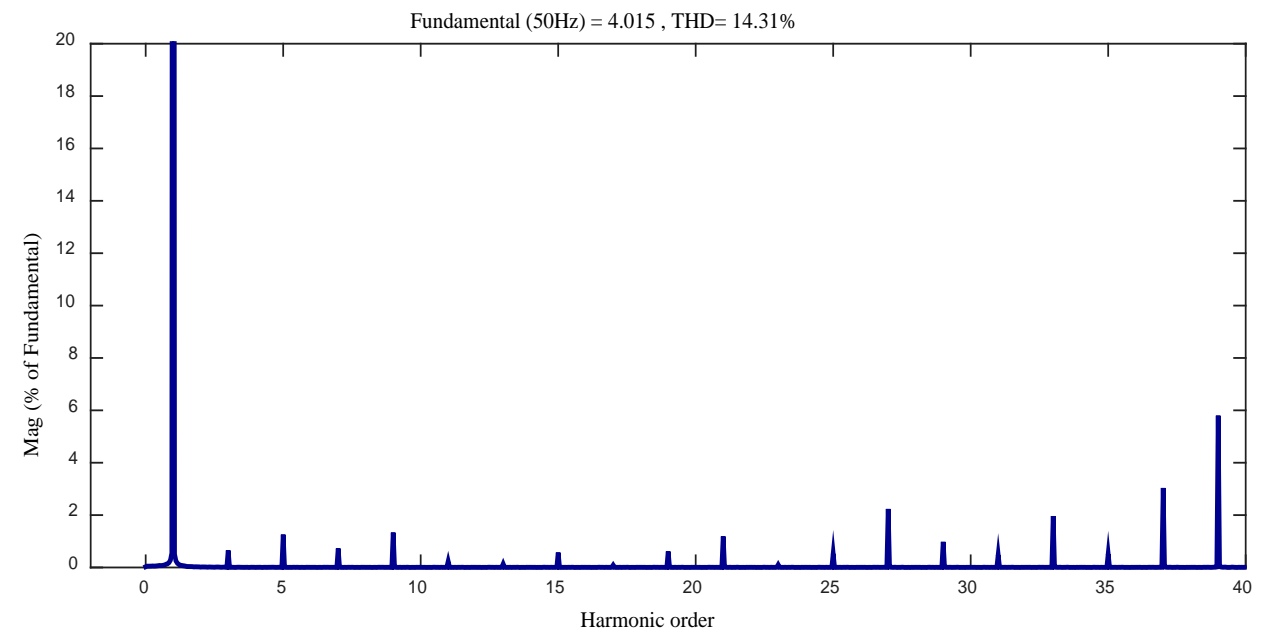

Figure 5. Current response of symmetrical current source inverter. 

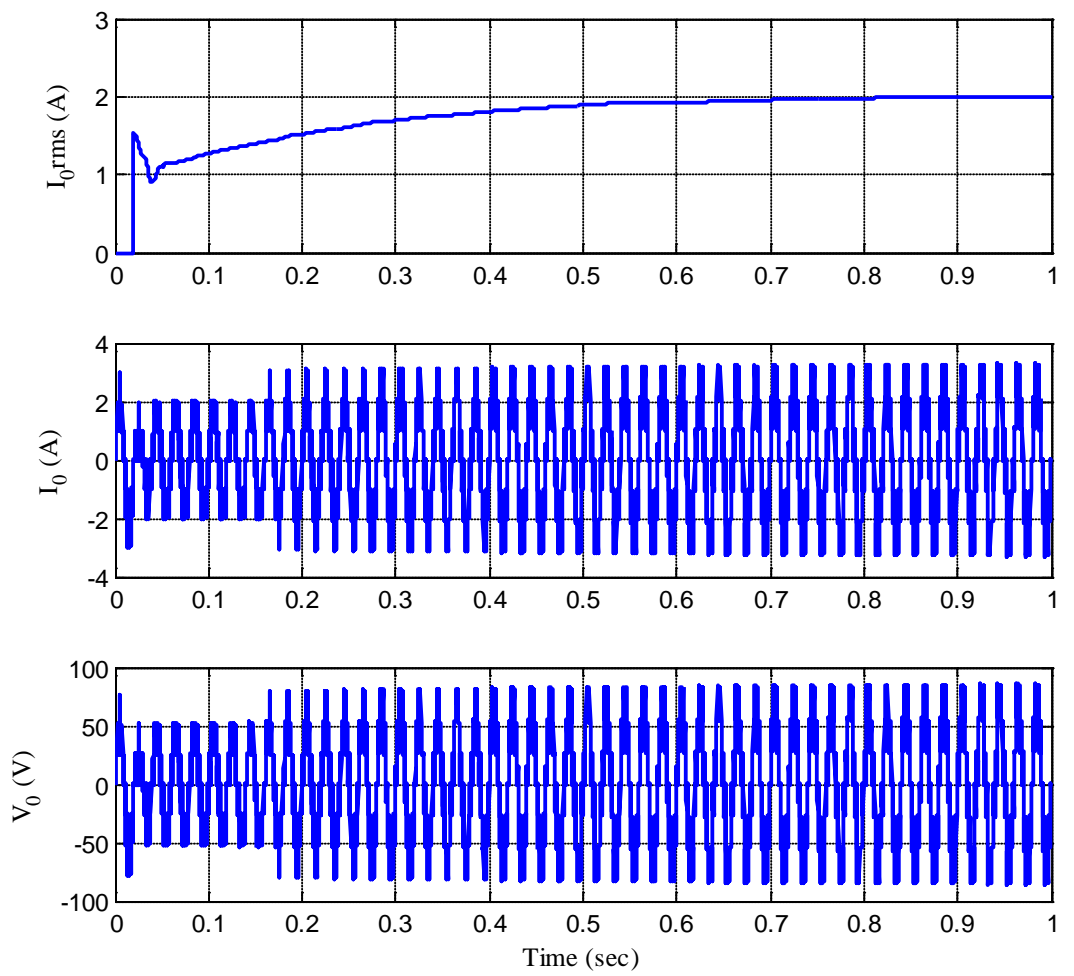

Figure 6. Closed loop PI controller Iorms, output current, and voltage response of symmetrical CSI (set value of $\mathrm{I}_{\mathrm{rms}}=2 \mathrm{~A}$ ).
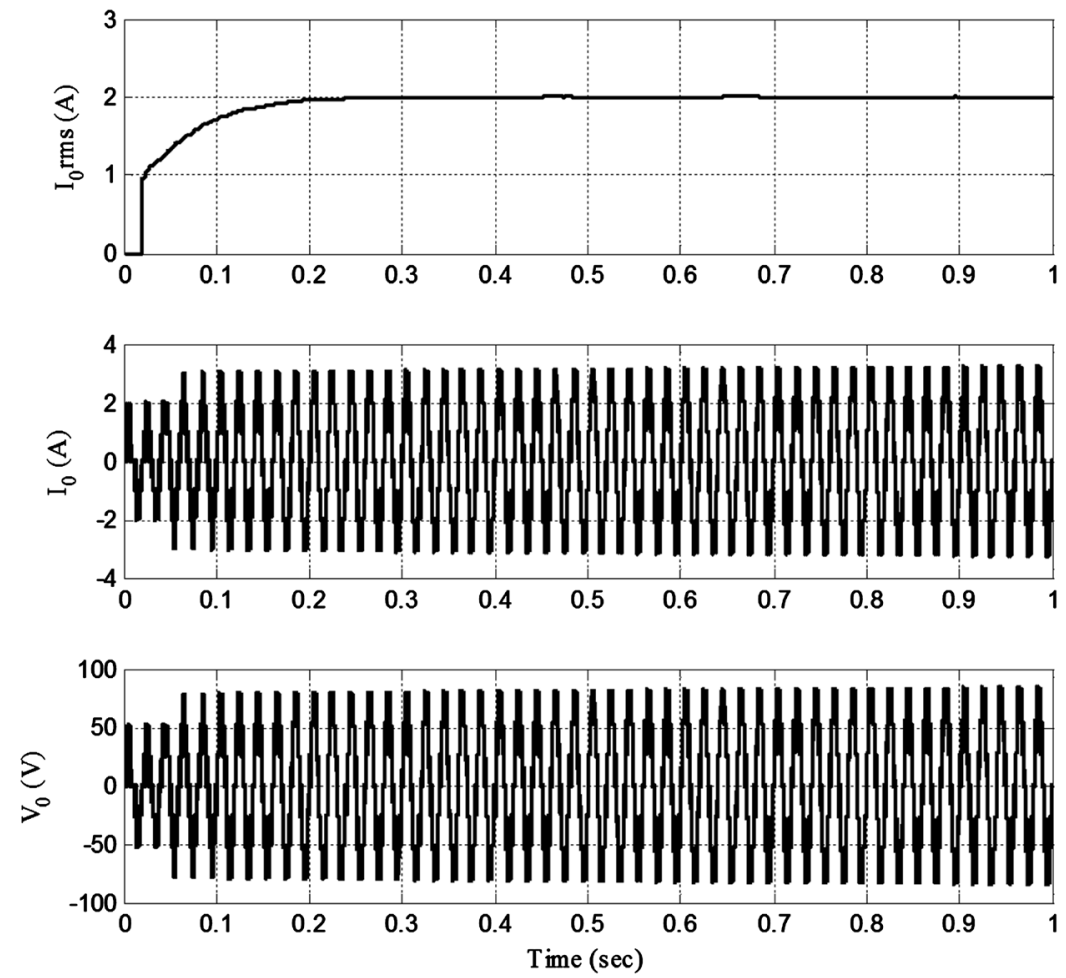

Figure 7. Closed loop Fuzzy PI controller Iorms, output current, and voltage response of symmetrical CSI (set value of $\mathrm{I}_{\mathrm{rms}}=2 \mathrm{~A}$ ). 


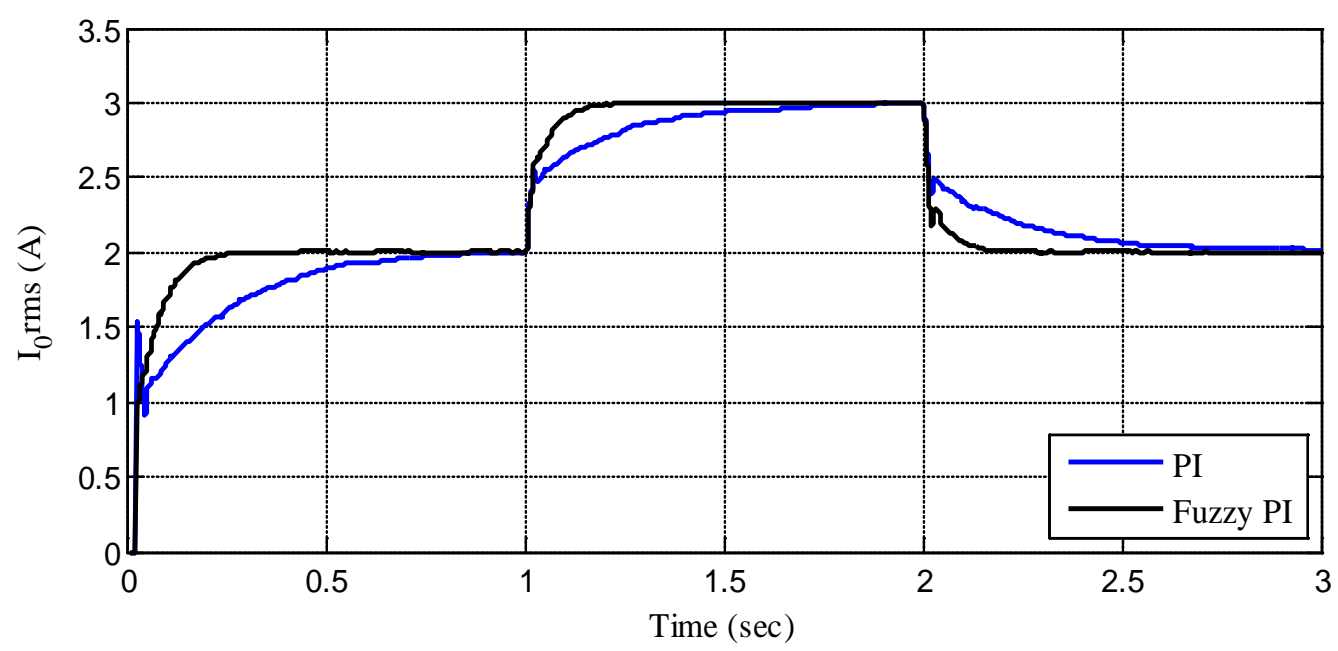

Figure 8. Current responses comparison of PI and Fuzzy controller of symmetrical CSI $\left(t=0 \mathrm{~s} ; \mathrm{I}_{0} \mathrm{rms}=2 \mathrm{~A} ; t=1-2 \mathrm{~s} ; \mathrm{I}_{0} \mathrm{rms}=3 \mathrm{~A} ; t=2\right.$ $s ; \mathrm{I}$ rrms $=2 \mathrm{~A}$ ).
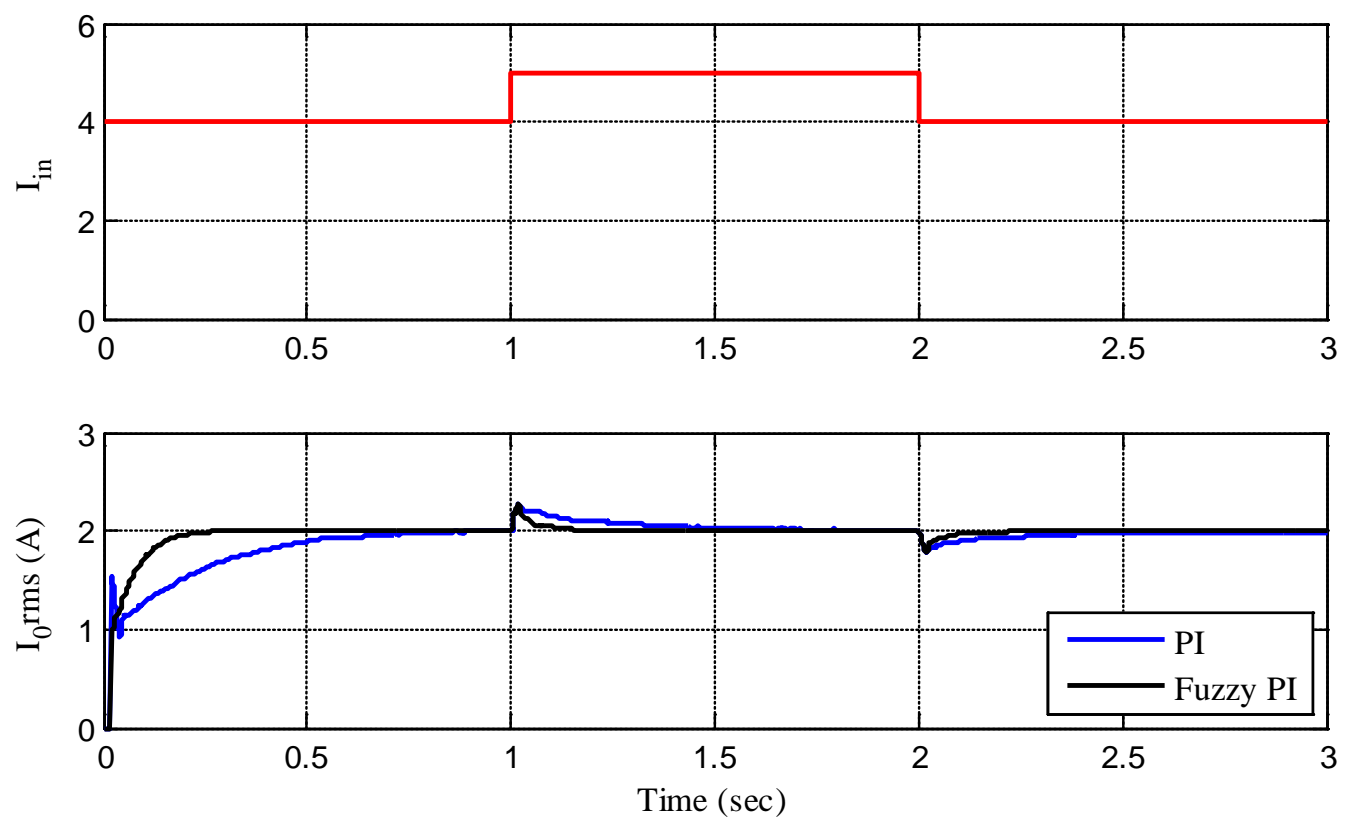

Figure 9. Current responses comparison of PI and Fuzzy controller of symmetrical CSI for change in load resistance.

Table 3. Performance evaluation of symmetrical CSI with resistive load using Matlab.

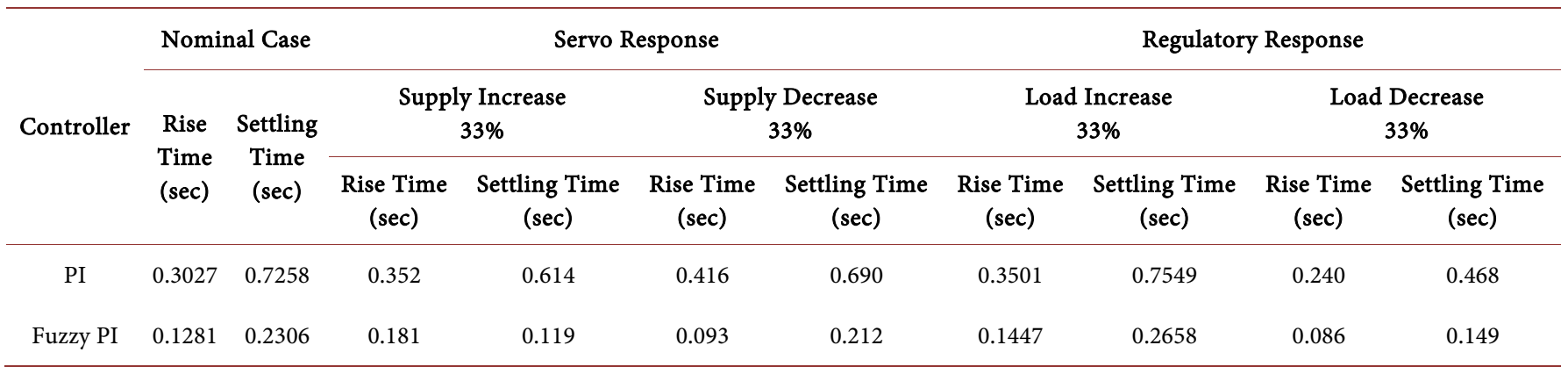


Figures 11-15 shows the overall simulated responses of the asymmetrical nine level single rating inductor current source inverter with PI and fuzzy PI controllers. Figure 11 and Figure 12 show the individual responses of asymmetrical nine-level current source inverter output current, voltage, and $\mathrm{I}_{\mathrm{rms}}$ tuned with PI controller and fuzzy PI controller respectively with a set value of $\mathrm{I}_{\mathrm{rms}}$ of 2 A. Figure 13 shows the output current responses of PI and fuzzy PI controllers. From this figure, it is observed that the fuzzy PI controller response has been settled at $0.637 \mathrm{sec}$, whereas the fuzzy PI controller tuned response settled at $0.39 \mathrm{sec}$, without any disturbances. Figure 14 shows the

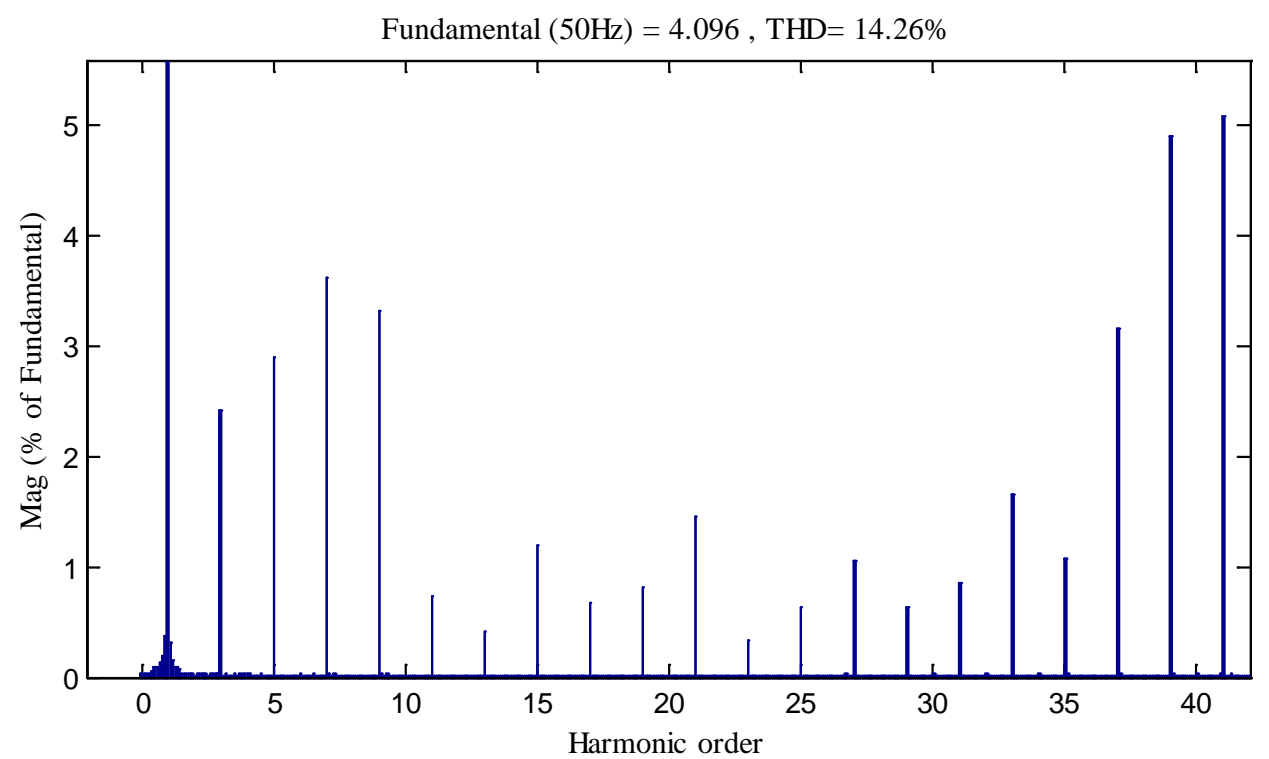

Figure 10. Current response of asymmetrical current source inverter.
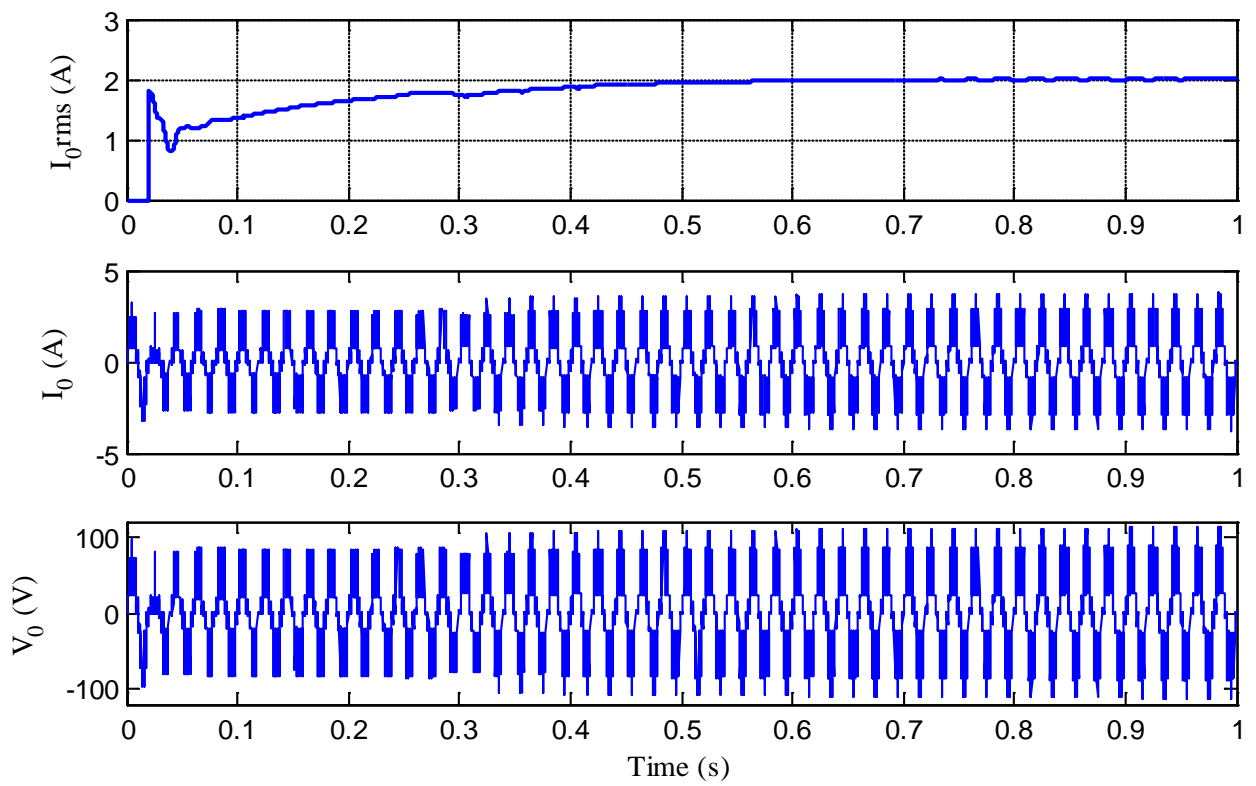

Figure 11. Closed loop PI controller Iorms, output current, and voltage response of asymmetrical CSI. 

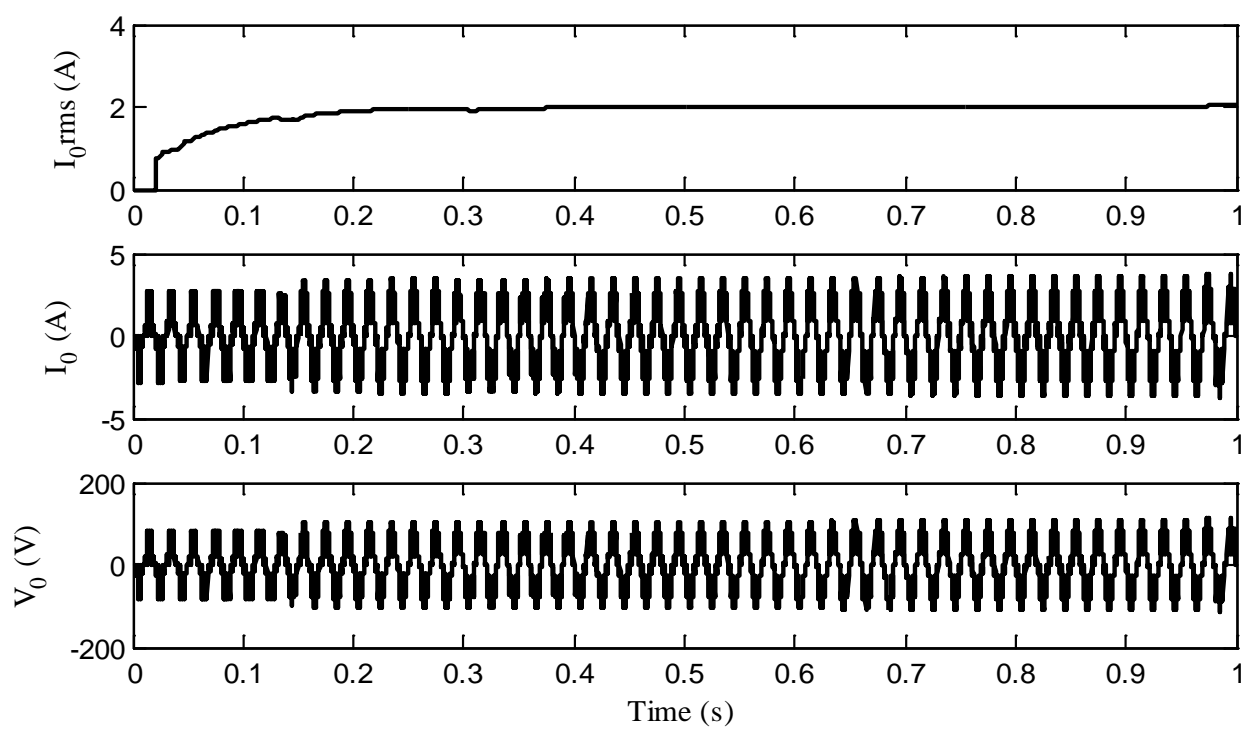

Figure 12. Closed loop Fuzzy PI controller Iorms, output current, and voltage response of asymmetrical CSI.

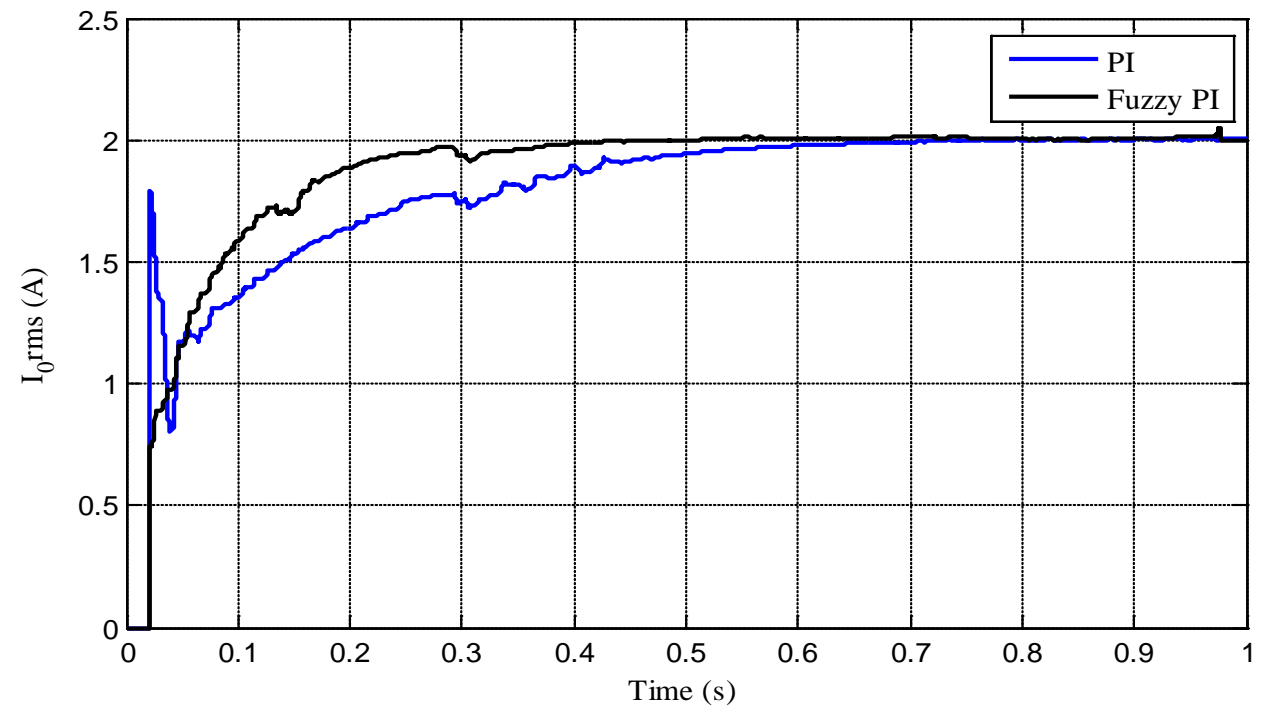

Figure 13. Current responses comparison of PI and Fuzzy controller of asymmetrical CSI.

current response comparison of PI and Fuzzy Controller of asymmetrical CSI for change in load current. During this regulatory response, the fuzzy PI controller response has been settled very fast with its reference current without any oscillation compared with PI controller. Similarly, the Figure 15 shows the current responses comparison of PI and Fuzzy Controller of asymmetrical CSI for change in input. From the Figure 15, it is noted that the input suddenly increased from $4 \mathrm{~A}$ to $5 \mathrm{~A}$ at $\mathrm{t}=1 \mathrm{~s}$ and back to $4 \mathrm{~A}$ at $\mathrm{t}=$ 2 s. During this servo response, the fuzzy PI controller response has been converged before PI controller. Table 4 shows the performance analysis of asymmetrical CSI using PI and Fuzzy Controller. Table 5 shows the comparison of symmetrical and asymmetrical CSI circuit. 


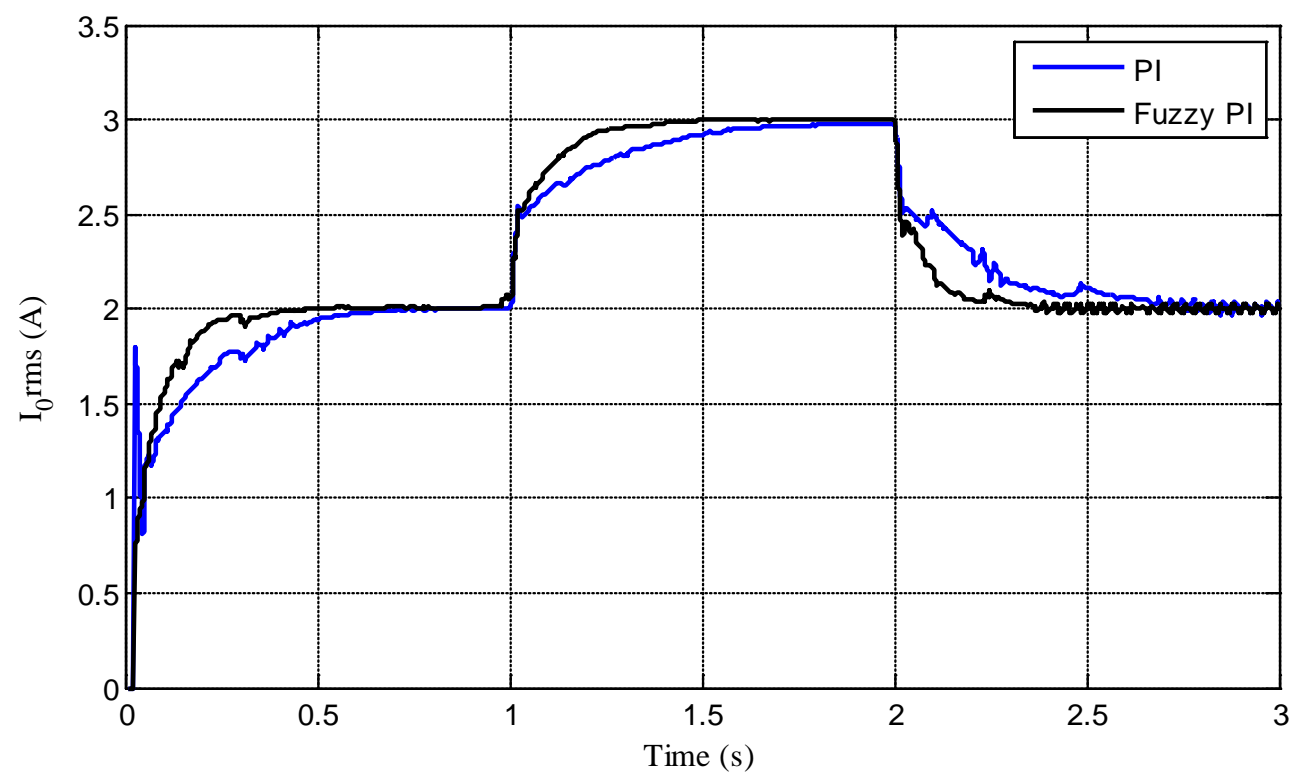

Figure 14. Current responses comparison of PI and Fuzzy controller of asymmetrical CSI for change in reference.
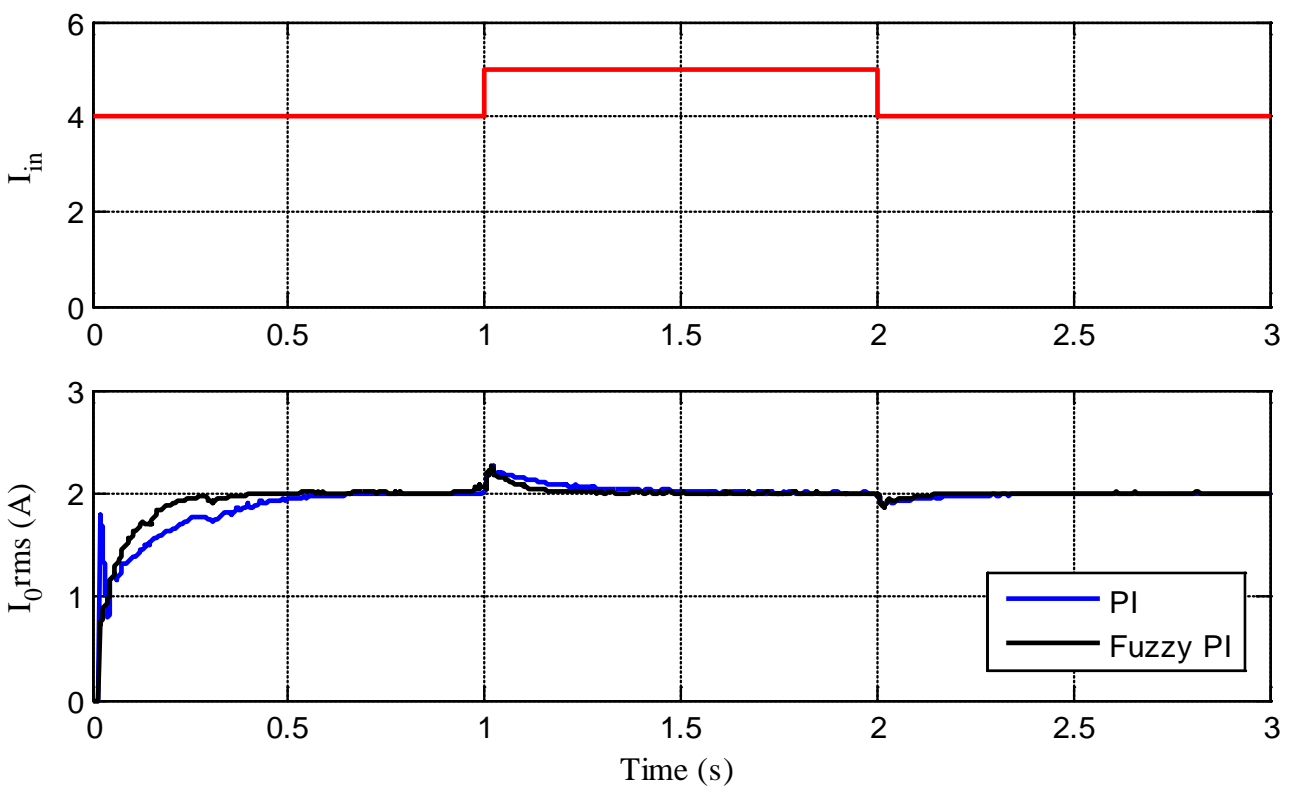

Figure 15. Current responses comparison of PI and Fuzzy controller of asymmetrical CSI for change in input voltage.

Table 4. Performance evaluation of asymmetrical CSI with resistive load using Matlab.

\begin{tabular}{|c|c|c|c|c|c|c|c|c|c|c|}
\hline \multirow{3}{*}{ Controller } & \multicolumn{2}{|c|}{ Nominal Case } & \multicolumn{4}{|c|}{ Servo Response } & \multicolumn{4}{|c|}{ Regulatory Response } \\
\hline & \multirow{2}{*}{$\begin{array}{l}\text { Rise } \\
\text { Time } \\
\text { (sec) }\end{array}$} & \multirow{2}{*}{$\begin{array}{c}\text { Settling } \\
\text { Time } \\
\text { (sec) }\end{array}$} & \multicolumn{2}{|c|}{ Supply Increase $33 \%$} & \multicolumn{2}{|c|}{ Supply Decrease 33\% } & \multicolumn{2}{|c|}{ Load Increase 33\% } & \multicolumn{2}{|c|}{ Load Decrease 33\% } \\
\hline & & & $\begin{array}{l}\text { Rise Time } \\
\quad(\mathrm{sec})\end{array}$ & $\begin{array}{l}\text { Settling Time } \\
\quad(\mathrm{sec})\end{array}$ & $\begin{array}{l}\text { Rise Time } \\
\quad(\mathrm{sec})\end{array}$ & $\begin{array}{l}\text { Settling Time } \\
\quad(\mathrm{sec})\end{array}$ & $\begin{array}{l}\text { Rise Time } \\
\quad(\mathrm{sec})\end{array}$ & $\begin{array}{l}\text { Settling Time } \\
\quad(\mathrm{sec})\end{array}$ & $\begin{array}{l}\text { Rise Time } \\
\quad(\mathrm{sec})\end{array}$ & $\begin{array}{l}\text { Settling Time } \\
(\mathrm{sec})\end{array}$ \\
\hline PI & 0.260 & 0.646 & 0.251 & 0.790 & 0.337 & 0.935 & - & 0.540 & - & 0.320 \\
\hline
\end{tabular}




\section{Experimental Analysis of Nine-Level Asymmetrical Current Source MLI}

From the simulated performance the asymmetrical nine-level inverter produced good results with less number of power electronics components. So the best circuit also implemented for experimental verification. The proposed asymmetrical nine level CSI was built and tested to assess its performance. $3 \mathrm{~A}$ DC used as a source by using $36 \mathrm{~V}$ and $100 \mathrm{~W}$ solar panel fed to the input of CSI circuit. The maximum power available was $100 \mathrm{~W}$, at an irradiance level of $1000 \mathrm{~W} / \mathrm{m}^{2}$, and a temperature of $25^{\circ} \mathrm{C}$. This power circuit consists of four IGBT switches IRG4PC40UD, $600 \mathrm{~V}$ and $20 \mathrm{~A}$, and two pairs of inductors of L11 and L12 whose values are $15 \mathrm{mH}$ and L21 and L22 are $5 \mathrm{mH}$. Arduino controller was programmed to provide the controlled switching sequences of the asymmetrical nine level CSI using fuzzy tuned PI controller technique. Finally, the output of nine level CSI generated and verified with different load changing conditions. Figures 16-20 show the experimental results of proposed asymmetrical nine level CSI.

Figure 16 shows the nine level output current waveform generation of asymmetrical current source inverter and Figure 17 shows the output voltage and current waveform

Table 5. Comparison of symmetrical and asymmetrical nine level single rating inductor CSI.

\begin{tabular}{ccc}
\hline Description & Symmetrical & Asymmetrical \\
\hline \%THD & 14.31 & 14.26 \\
$\mathrm{I}_{\mathrm{rms}}$ in Amps & 4.015 & 4.096 \\
No. of switched required & 16 & 8 \\
No. of inductors required & 8 & 4 \\
\hline
\end{tabular}

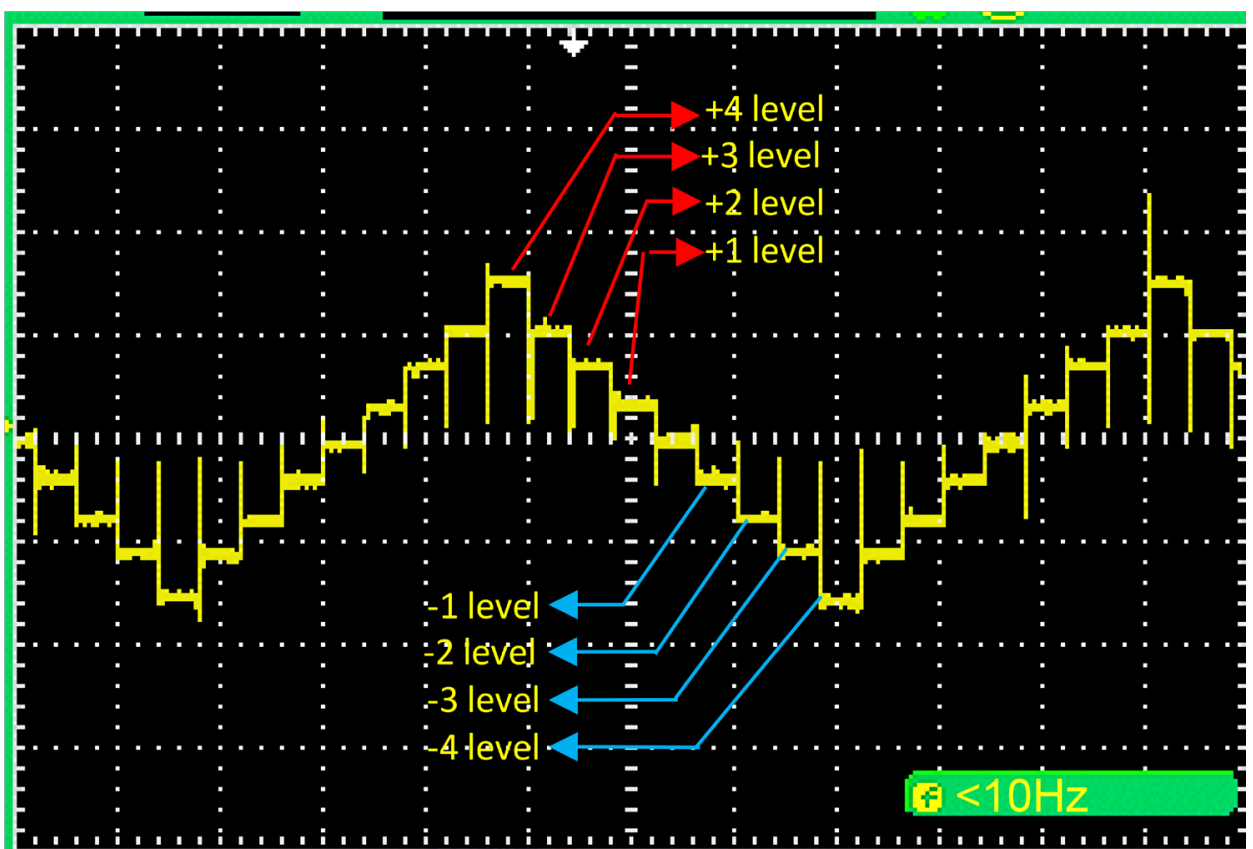

Figure 16. Nine level current waveform generation of asymmetrical current source inverter. 


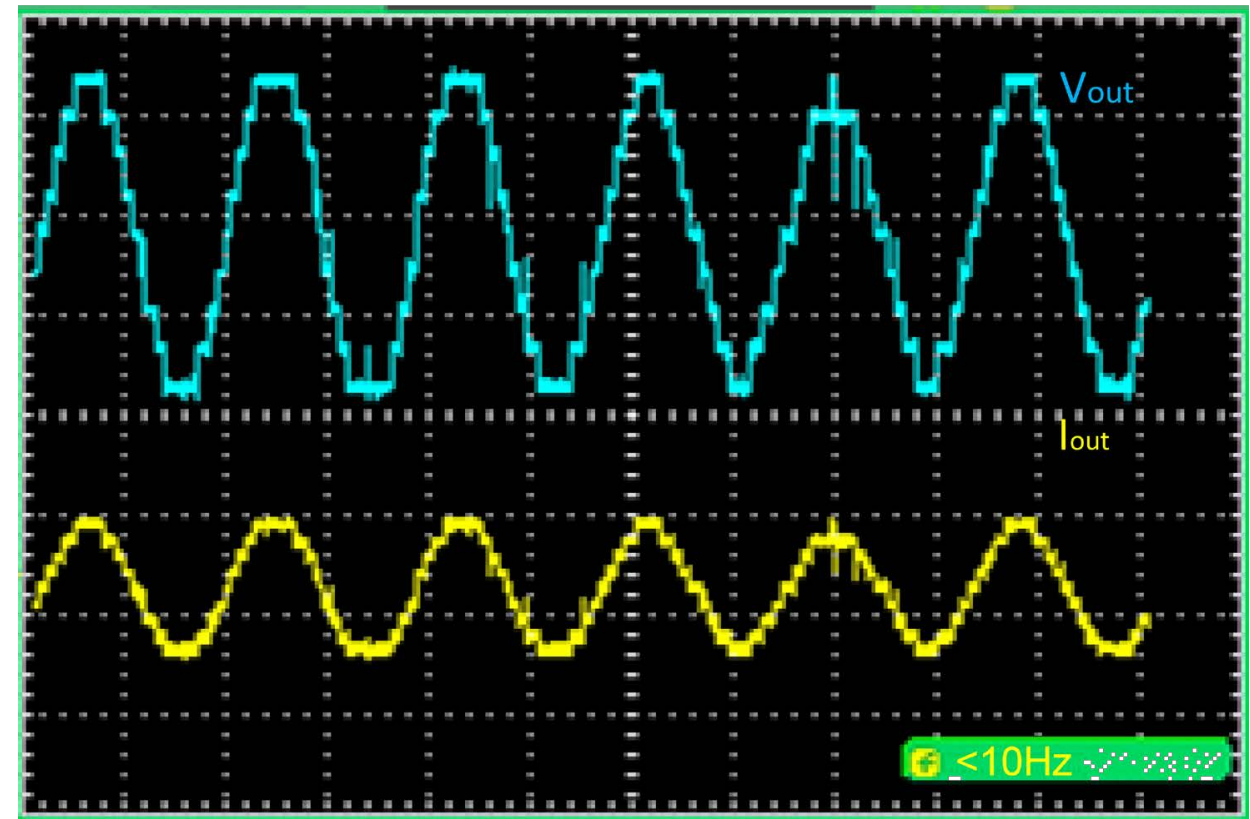

Figure 17. Output voltage and current waveform of asymmetrical current source inverter.

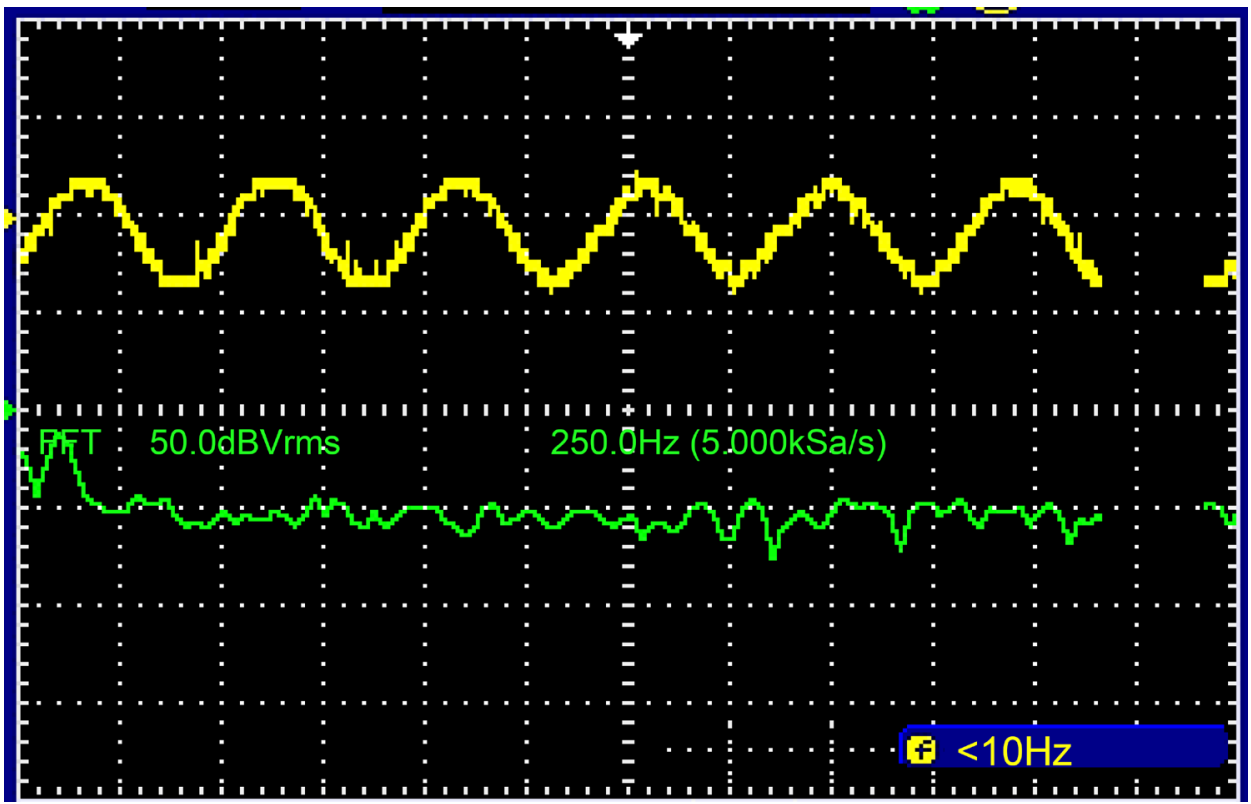

Figure 18. Current harmonic FFT of asymmetrical current source inverter.

of proposed CSI. Figure 18 shows the FFT screen of output current waveform of CSI. Figure 19 and Figure 20 shows the output current waveform at different load changing conditions with and without controller compensation. Topology wise the asymmetrical inverter is economical with less number of components to achieve the same (nine) level compared with symmetrical CSI. The switching and conduction losses minimized due to the presence of fewer components in the power circuit of asymmetrical CSI. The experimental results are also proved the same. The proposed topology uses reduced 


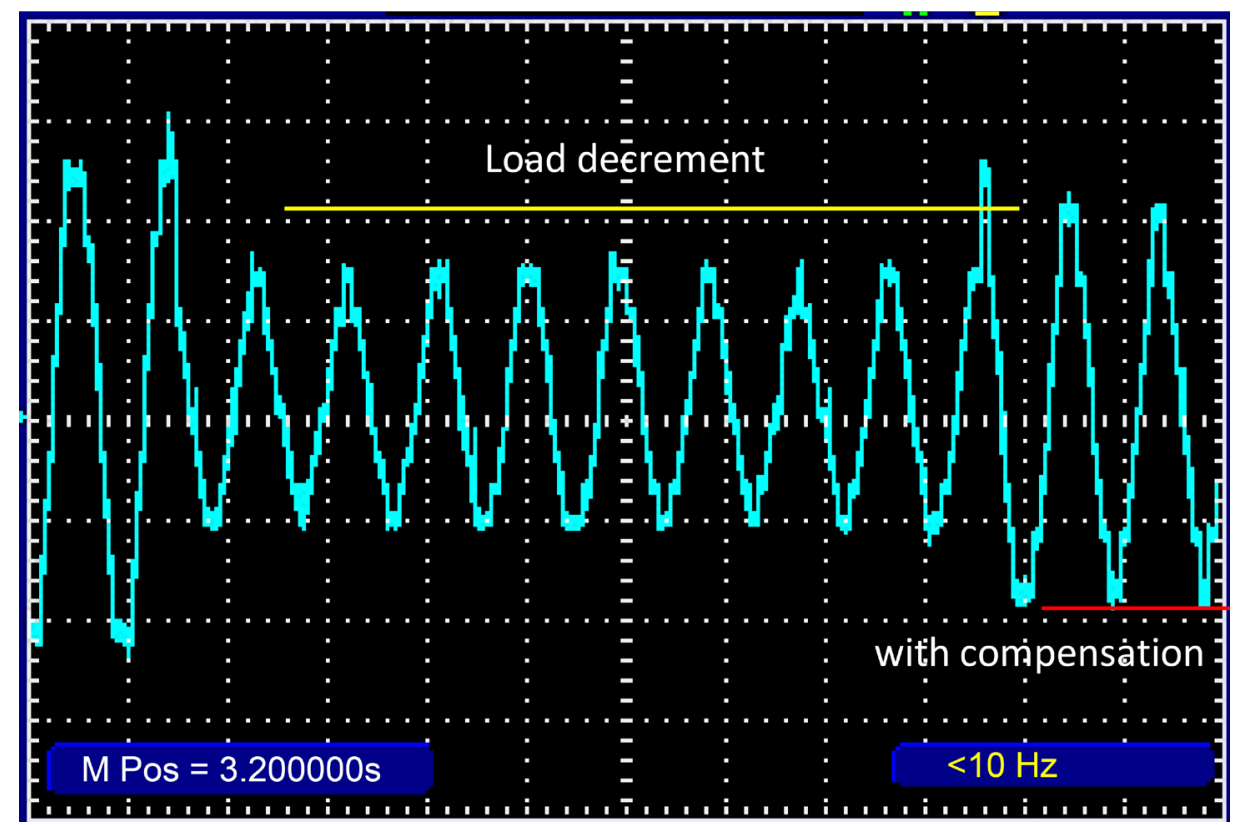

Figure 19. Output current during load increment with Fuzzy PI controller.

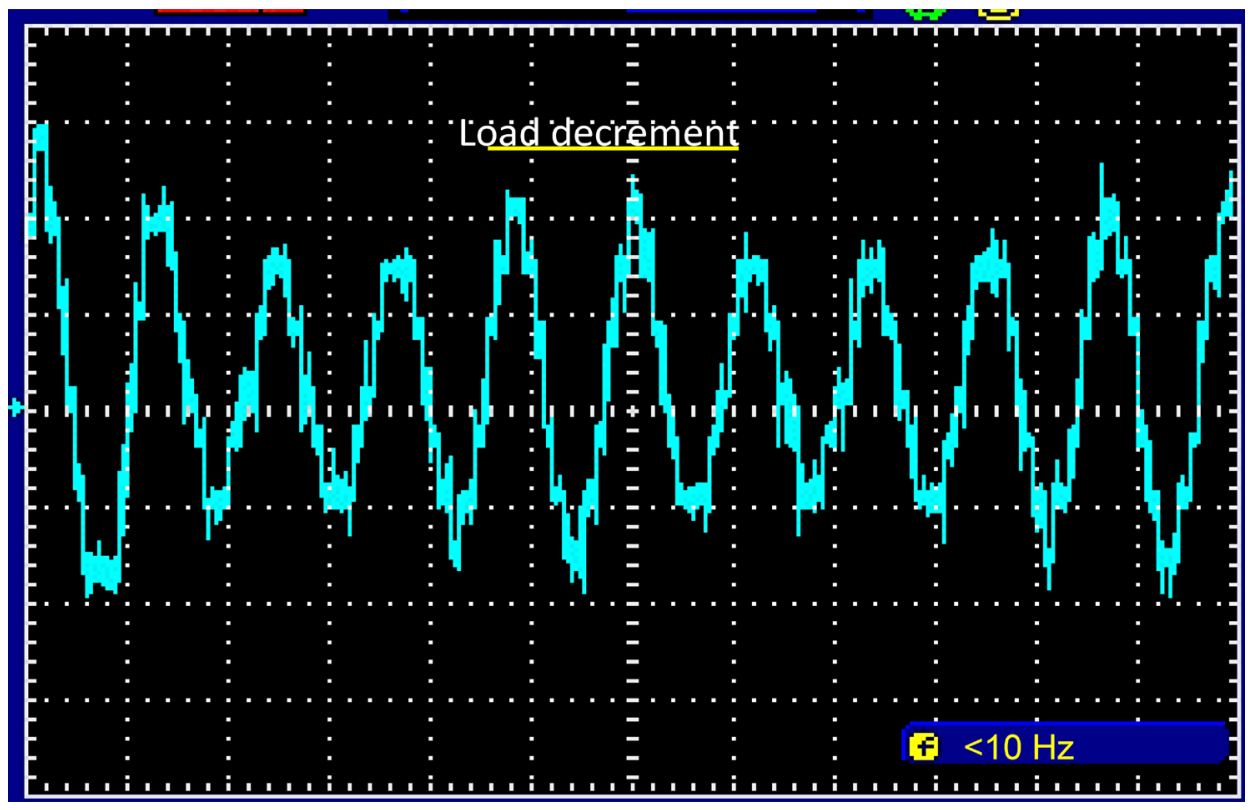

Figure 20. Output current during load changes with Fuzzy PI controller.

number of switches and is able to produce the desired output current while the current balance between current-sharing inductors is guaranteed using appropriate control method. Output current waveform and current balance between current-sharing inductors are completely satisfied.

\section{Conclusion}

In this work, an important assessment of Current Source Multilevel Inverter (CSMLI) 
has been presented. It draws a low-ripple current from the PV cells, therefore maximizing its performance. The inverter is built with state-of-the-art power devices that have fast switching times. The overall performance analysis of proposed symmetrical and asymmetrical nine-level single phase single inductor current source inverter is tabulated in Tables 3-5. From the Table 5, it is observed that the asymmetrical CSI circuit provided a good \%THD and steady state analysis controlled by PI and fuzzy PI controllers at different operating conditions. Based on topology wise the asymmetrical inverter is economical with less number of components to achieve the same (nine) level compared with symmetrical CSI. The switching and conduction losses minimized due to the presence of fewer components in the power circuit of asymmetrical CSI. The experimental results are also proved the same. The proposed topology uses reduced number of switches and is able to produce the desired output current while the current balance between current-sharing inductors is guaranteed using appropriate control method. Output current waveform and current balance between current-sharing inductors are completely satisfied.

\section{References}

[1] Li, Z., Wang, P., Li, P. and Gao, F. (2012) A Novel Single-Phase Five Level Inverter with Coupled Inductors. IEEE Transaction on Power Electronics, 27, 2716-2725. http://dx.doi.org/10.1109/TPEL.2011.2176753

[2] Banaei, M.R., Dehghanzadeh, A.R., Salary, E. and Khounjahan, H. (2012) Z-Source-Based Multilevel Inverter with Reduction of Switches. IET Power Electronics, 5, 385-392. http://dx.doi.org/10.1109/TPEL.2011.2176753

[3] Mittal, N., Singh, B., Singh, S.P., Dixit, R. and Multi-Level Inverter (2012) A Literature Survey on Topologies and Control Strategies. Proceedings on Power, Control and Embedded Systems, Allahabad, December 2012, 1-11.

[4] Carrara, G., Gardella, S., Marchesoni, M., Salutari, R. and Sciutto, G. (1992) A New Multilevel PWM Method: A Theoretical Analysis. IEEE Transactions on Industrial Electronics, 7, 497-505.

[5] Rodriguez, J., Correa, P. and Moran, L. (2002) A Vector Control Technique for Medium Voltage Multilevel Inverters. IEEE Transactions Industrial Electronics, 49, 882-888. http://dx.doi.org/10.1109/TIE.2002.801235

[6] Barbosa, P.G., Braga, H.A.C. and Teixeira, E.C. (2006) Boost Current Multilevel Inverter and Its Application on Single Phase Grid Connected Photovoltaic System. IEEE Transactions on Power Electronics, 21, 1116-1124. http://dx.doi.org/10.1109/TPEL.2006.876784

[7] Suroso, T.N. (2014) A Single-Phase Multilevel Current Source Converter Using H-Bridge and DC Current Modules. International Journal of Power Electronics and Drive System (IJPEDS), 4, 165-172. http://dx.doi.org/10.11591/ijpeds.v4i2.5603

[8] Klumpner, C. and Blaabjerg, F. (2006) Using Reverse Blocking IGBTs in Power Converters for Adjustable-Speed Drives. IEEE Transactions on Industry Applications, 42, 807-816. http://dx.doi.org/10.1109/TIA.2006.872956

[9] Kwak, S. and Toliyat, H.A. (2006) Multilevel Converter Topology Using Two Types of Current-Source Inverters. IEEE Transactions on Industry Applications, 42, 1558-1564. http://dx.doi.org/10.1109/TIA.2006.882645

[10] Xu, D., Zargari, N.R., Wu, B., Wiseman, J., Yuwen, B. and Rizzo, S. (2005) A Medium 
Voltage AC Drive with Parallel Current Source Inverters for High Power Applications. Proceedings in Power Electronics Specialists Conference, Recife, June 2005, 2277-2283. http://dx.doi.org/10.1109/pesc.2005.1581949

[11] Wiseman, J. and Wu, B. (2005) Active Damping Control of a High Power PWM Current Source Rectifier for Line Current THD Reduction. IEEE Transactions on Industrial Electronics, 52, 758-764. http://dx.doi.org/10.1109/TIE.2005.843939

[12] Suroso, S. and Noguchi, T. (2012) Multilevel Current Waveform Generation Using Inductor Cells and H-Bridge Current Source Inverter. IEEE Transactions on Power Electronics. 27, 1090-1098. http://dx.doi.org/10.1109/TPEL.2010.2056933

[13] Bai, Z.H. and Zhang, Z.C. (2008) Conformation of Multilevel Current Source Converter Topologies Using the Duality Principle. IEEE Transactions on Power Electronics, 23, 2260-2267. http://dx.doi.org/10.1109/TPEL.2008.2001893

[14] Antunes, F.L.M., Braga, H.A.C. and Barbi, I. (1999) Application of a Generalized Current Multilevel Cell to Current Source Inverters. IEEE Transactions on Power Electronics, 46, 31-38. http://dx.doi.org/10.1109/41.744373

[15] Suroso, S. and Noguchi, T. (2010) New H-Bridge Multilevel Current-Source PWM Inverter with Reduced Switching Device Count. Proceedings in IEEE Power Electronics Conference, Sapporo, June 2010, 1228-1235. http://dx.doi.org/10.1109/ipec.2010.5544637

[16] Bao, J., Holmes, D.G., Bai, Z., Zhang, Z. and Xu, D. (2006) PWM Control of a 5-Level Single-Phase Current-Source Inverter with Controlled Intermediate DC Link Current. Proceedings of Power Electronics Specialists Conference, Jeju, 18-22 June 2006, 1-6. http://dx.doi.org/10.1109/PESC.2006.1712008

[17] McGrath, B.P. and Holmes, D.G. (2008) Natural Current Balancing of Multicell Current Source Inverters. IEEE Transactions on Power Electronics, 23, 1239-1246. http://dx.doi.org/10.1109/TPEL.2008.921166

[18] Vazquez, N., Lopez, H., Hernandez, C., Vazquez, E., Osorio, R. and Arau, J. (2010) A Different Multilevel Current-Source Inverter. IEEE Transactions on Industrial Electronics, 57, 2623-2632. http://dx.doi.org/10.1109/TIE.2009.2030814

[19] Torres-Salomao, L.A. and Gámez-Cuatzin, H. (2012) Fuzzy Logic Control and PI Control Comparison for a 1.5 MW Horizontal Axis Wind Turbine. Proceedings of System Theory, Control and Computing, Sinaia, 12-14 October 2012, 1-6.

[20] Xiong, Y., Li, Y., Yang, X. and Zhang, Z. (2005) A New Three-Phase 5-Level CurrentSource Inverter. Proceedings of the 20th Annual IEEE Applied Power Electronics Conference and Exposition, 1, 424-427r.

[21] Bao, J.Y. (2010) Generalized Multilevel Current Source Inverter Topology with Self-Balancing Current. Journal of Zhejiang University-SCIENCE C (Computers \& Electronics), 11, 555-561. http://dx.doi.org/10.1631/jzus.C0910605

[22] Shen, J.C. (2002) New Tuning Methods for PID Controller. ISA Transactions, 41, 473-484. http://dx.doi.org/10.1016/S0019-0578(07)60103-7

[23] McGrath, B.P. and Holmes, D.G. (2002) Multicarrier PWM Strategies for Multilevel Inverters. IEEE Transactions on Industrial Electronics, 49, 858-867. http://dx.doi.org/10.1109/TIE.2002.801073

[24] Wu, J.-C. and Chou, C.-W. (2013) A Solar Power Generation System with a Seven-Level Inverter. IEEE Transactions on Power Electronics, 29, 3454-3462. http://dx.doi.org/10.1109/TPEL.2013.2279880

[25] Boost, M.A. and Ziogas, P.D. (1988) State-of-the-Art Carrier PWM Techniques: A Critical Evaluation. IEEE Transactions on Industry Applications, 24, 271-280.

http://dx.doi.org/10.1109/28.2867 
Submit or recommend next manuscript to SCIRP and we will provide best service for you:

Accepting pre-submission inquiries through Email, Facebook, LinkedIn, Twitter, etc. A wide selection of journals (inclusive of 9 subjects, more than 200 journals)

Providing 24-hour high-quality service

User-friendly online submission system

Fair and swift peer-review system

Efficient typesetting and proofreading procedure

Display of the result of downloads and visits, as well as the number of cited articles

Maximum dissemination of your research work

Submit your manuscript at: http://papersubmission.scirp.org/ 